\title{
THE EFFECT OF GAMES ON VOCABULARY RETENTION
}

\author{
Yasmin Shabaneh \\ English Department, Faculty of Arts, Hebron University, Palestine \\ E-mail: yasminshabaneh82@gmail.com \\ Mohammed Farrah \\ English Department, Faculty of Arts, Hebron University, Palestine \\ E-mail:mfarrah@hebron.edu
}

\begin{abstract}
APA Citation: Shabaneh, Y., \& Farrah, M. (2019). The effect of games on vocabulary retention. Indonesian Journal of Learning and Instruction, 2(1), 79-90. doi: 10.25134/ijli.v2i01.1687.
\end{abstract}

Abstract: Learning English has become a necessity during this century. Consequently, it is utilized in different institutions in Palestine such as schools, universities, hospitals, etc. Therefore, it is taught in schools by using different methods. Thus, in order to comprehend the language efficiently, it has to be taught in creative and interesting methods and using games inside the classroom in one of these methods. The study aims to figure out the efficiency of using games inside classrooms and to answer the research questions. The study was conducted during the first semester of 2018/2019, in which 20 participants were enrolled. The researchers collected data using pretest; posttest and class observation. The study continued for two months. In that, students were introduced to unfamiliar vocabulary through games. The findings of the research revealed the efficiency of utilizing games in the educational process. Accordingly, games help students to retain unfamiliar vocabulary, to associate new information with their surroundings and to develop their language and communicative skills.

Keywords: collaborative learning; educational games; enjoyment; motivation; vocabulary.

\section{INTRODUCTION}

Learning the English language has become essential to all people because of its dominance of all aspects of life. Consequently, it is utilized in different institutions in Palestine such as schools, universities, hospitals, etc. Yet, learning this language relies on English classes at schools which results in graduating a number of preservice teachers who have pronunciation difficulties (Shehadeh \& Farrah, 2016; Jabali \& Abuzaid, 2017), spelling mistakes (AlSaqqaf and Busaidi, 2015), and writing troubles (Rass, 2015). Thus, improving the language skills of learners requires developing, modifying, or changing the approaches used at schools to teach this language (Nuraihan \& Farrah, 2013; Saha \&
Singh, 2016). Therefore, it is of importance to emerge novel teaching style and to focus on student-centered teaching methods, which would result in graduating students who are able to comprehend the language and to communicate efficiently.

Using games in learning environments is deeply rooted in several learning theories (interactionists theories, experiential theories). (1938) advocated learning experiences that encourage meaningful learning. According to him, real learning takes place if learners engaged actively with the content in a meaningful context.. Likewise, Kolb (1984) deems that experiential learning is a dynamic facet in engaging the learners. Accordingly he believes that "learning is the process 
whereby knowledge is created through the transformation of experience" (p. 38).

Student-centered methods and strategies ought to be applied from early ages because children are curious by nature and self-reliant in discovering their surroundings. Students-centered teaching, in fact, meets young learners' genius which help students and teachers in the teaching-learning process (Abuzahra, Farrah, \& Zalloum, 2016). Then, learners at this age are more creative, so teachers can deliver information in a diversity of simple, yet interesting and informative ways. Using engaging activities increases maximizes interaction and collaboration among learners (Farrah, 2011; Farrah, 2014). Unlike adults, young learners understand languages easily. When they are exposed to a language input for a period of time, they start making connections and communicating effectively. Concerning the educational process, there are a few questions that need to be answered. First of all, does the traditional method of teaching fulfill young students' needs, or creativity needs to be present to help students gain as much information as required? Games are invaluable for practicing the four language skills. They maximize learners' motivation and interaction as they find opportunities to use language in meaningful contexts. Therefore, the playing language games may contribute to meet some requirements of second language acquisition such as exposure, use, collaboration and motivation (Willis, 1996). Learners play games collaboratively in an entertaining learning environment. The learning process becomes enjoyable and interesting (Saha \& Singh, 2016).

Different linguists and scholars dedicated their lives to both improve and simplify the language learning process for students through looking deep into the best possible methods and approaches to follow in this process:

First, the Grammar-Translation method, the dominant method used in schools in Palestine to teach the English language, is not regarded as the best teaching approach by many linguists. In fact, linguists and researchers failed to find any literature or theory that advocates the GrammarTranslation method or relates it to issues concerning linguistics, psychology, or educational theory. For example, Richards and Rodgers (2014) assert that GrammarTranslation method does not aim at teaching students the language itself, but teaching them about the language. In other words, this method does not serve in rendering students ability of comprehension or oral production of the language, but it might serve in teaching them the grammatical rules and some vocabulary. Richards and Rodgers (2014) found that this method serves best in teaching a language in which understanding the literary text is the main focus rather than improving the capacity of oral production or comprehension of the language.

Moreover, it creates frustration for students because, according to Benoit (2017), it is very demanding on its behalf; it is based on translating whatever students learn directly into their native tongue. In simpler terms, students learn the grammatical rules of the target language and a great deal of written vocabulary and then translate into their native language to be able to memorize what they have learned.

Furthermore, the second approach is the Communicative Approach. According to Celik (2014) this approach "does not constitute a method in itself", yet it frames the overall understanding of language teaching which might be carried out in different methods, or it can be perceived as "principles about the goals of language teaching" Richards (2006). This approach views language as a tool that people use in order to socialize. Also, culture is considered an influential factor upon learners' competence and personality. According to this method, to learn a language you must engage and communicate in it. So, the activities that can be carried out are limited only to the creativity of the teacher, learner, and the curriculum.

As Nunan (1989) demonstrates, the aims of this approach are to communicate, to 
maintain relationships, to use the language in our daily activities to develop our communicative competence. In contrast to other approaches, this method is considered student-centered, where the teacher is only considered to be responsible for learners' language needs (Richards and Rodgers 2014) which gives the student more space to be creative (Yavuz, 2010) and confident (Safraz et al. 2015). Games, in all its forms, can be a major factor in the teaching process according to this approach because they fulfill the mentioned aims and result in a better understanding of the language and the learning process.

In addition, active learning was introduced to the teaching process which is defined as "any instructional method that engages learners in the learning process" (Moore, 2016). In other terms, active learning refers to exposing learners to different activities (games, or internet-based teaching) that help them to interact with their peers, or teachers; develop higher thinking and not only act as information recipients. Approaches that advocate active learning support the idea of makin connections between new concepts and existing ones to experience better understanding. In order to develop learners' abilities, group work is encouraged (Adams, 2016) where it allows students to exceed their progress and extend their mental models. This concept was invented in opposition to Instructivism in which students are considered to be passive agents in the learning process (Onyesolo et al. 2013) and that information is transmitted from the teacher or textbook to students without them critically or logically analyzing it. That is, active learning promotes untraditional classroom activities that include students experimenting and exploring new ideas and information through games, which offers better comprehension of new concepts and ideas.

The English language consists of different aspects and each one is of its importance, yet a number of linguists such as Widdowson (1989) and Mckeown (2002) consider vocabulary to be the heart of the language. Wilkins (1972) stated, "While without grammar little can be conveyed, without grammar nothing can be conveyed". In other words, knowing Grammar rules helps people to compose structurally correct sentences, whereas knowing the correct vocabulary helps people to communicate. Ferreira (2007) suggests that people need to know $97 \%$ of the vocabulary in a text in order for them to gain an adequate understanding of it. This means that in order for people to express themselves, and be understood by others, both sides (senderrecipient )need to be acquainted with a sufficient amount of vocabulary.

Different scholars, linguists, and teaching approaches support untraditional teaching methods in which novel ways are applied inside and outside the classroom. These ways may include internet, online games or online assignments. It is to be mentioned that there is a consensus on the benefits of using games as a tool for teaching English language:

First, games create an interesting and fun learning atmosphere (Derakhshan \& Khatir, 2015 \& Lorenzutti, 2016 \& Quispe, 2016) in which students are motivated to learn and participate in class (Khatir, 2015 \& Quispe, 2016). Since games are based on actions rather than explanations, they capture attention and sustain motivation (Schifter, 2013). According to Garris et al. (2002) games succeed in increasing students' interest in subjects which enhances their concentration during class. Moreover, imagination and fantasy generally stimulate learners thinking. Therefore, it is beneficial to use it and link it playing educational because if the imaginary is thoughtprovoking, then the content becomes stimulating. In addition to the mentioned above, games usually have a clear and specific goal, for this reason, they trigger critical attention and motivation (Saha \& Singh, 2016). Thus, whenever the outcome does not meet the aims of the game, learners would put more effort or attention, and attempt to reduce the fault and achieve what is required. 
Secondly, contextualized information stimulates students' critical thinking, for whenever learners encounter new information, within the game, they link the information and situation together (Sardone, 2010). Also, when we use game-based teaching, we help creating and growing flexible individuals who are able to reason and adapt in real life situation (Zirawaga et al. 2017). According to Milczynski (2011), when learners play games, they learn to evaluate, synthesize, analyze and organize information. Furthermore, when students are interested in the games and feel the sense of friendly competition, they "grasp the complexity of problem-solving" and become more encouraged to think of different ways to solve the game (McDonald, 2017).

Thirdly, enjoyment is characterized as "the core experience of all entertainment media, including games" (Quick et al. 2012). While playing games, learners do not think of their worries and escape daily routines, which gives them space to enjoy themselves (Wechselberger, 2013). As stated by Giannakos (2013), enjoyment measures how the game helps achieve the objectives of the lesson and the usefulness of the game. Amusement, also, affects motivation (Iten \& Petko, 2013). In other words, the greater the enjoyment that is experienced, the greater interest is invested in practicing a certain game. In addition to the fact that games produce feelings of passionate enjoyment (Raba, 2014), delight is usually stimulated by the challenge which games provide to players (Sweetser \& Wyeth, 2018). This feeling of challenge makes learners existed and eager to top their peers.

In relation to what is mentioned above, games introduce friendly competition (Derakhshan \& Khatir, 2015), and it encourages cooperative, group work and enhances group dynamic (Milczynski, 2011). Moreover, games help students make visualauditory associations between pictures and pronunciation (Gruss, 2016). Also, games in the learning process help students to retain vocabulary more quickly and easily (Derakshan, 2015 \& Bavi, 2018). Those researchers and many others clarify the benefits of using games in a language classroom.

Different studies were conducted regarding this aspect, in which scholars experimented the effect of using games as a tool for teaching English language vocabulary. For instance, Gruss (2016) conducted a study to see the effectiveness of using games as a tool to teach vocabulary to young learners. The study involved 67 participants at the age of 6-7 who were chosen from different kindergartens. The researcher divided the participants into 3 groups (group A had 24 consisted of 24 students, group B consisted of 20 students and group $\mathrm{C}$ consisted of 23 students). There were three data collecting instruments 1 . An observational sheet 2 .

Vocabulary test 3. Picture based survey. The study focused on three games which are "spider is coming", a board with shapes and colors and a board game with colorful sheets. The study lasted one and a half months. The results showed a difference in performance among groups. The mistakes made by group A lowered as students played the games. the mistakes went from $63 \%$ (first game) to $38 \%$ (the second game), to $21 \%$ (the third game). Group B results were somewhat similar to group A, the mistakes made by students were $60 \%$ (first game), $50 \%$ (second game), and $25 \%$ (third game). However, group c had different results. The percentage of mistakes was low at the first game $26 \%$, yet it increased during the second game to $39 \%$, for it to decrease again with the third game 26\%. According to the analysis of this study, it is beneficial to use games in teaching where students make visual- auditory associations between pictures and pronunciation. Moreover, it is important to notice and explore what children like and don't like most, and how they react to certain games to have the maximum effect as the educational process continues.

Quispe (2016) conducted a study in Americana Adventist school - Juliaca city. 40 students of the $3^{\text {rd }}$ year of primary school were randomly chosen for this research. The 
researcher divided the participants into two groups, control and experimental. The instrument utilized for the study was a vocabulary test (pretest, posttest) that was divided into six sections of overall 20 points. To analyze the results, the researcher used Microsoft Excel and found that both groups, control and experimental, scored from 0-10 in their pretest which indicates that all participants are beginners. Also, the experiment group got an average of 4.9 and the control group got an average of 3.75 which means that the two groups started at merely the same average of vocabulary knowledge. The results of the posttest indicated that $40 \%$ of the students of the experimental group scored from 0-10, $25 \%$ students scored from 11-13, 35\% students got from 14-16 and 0\% got from 17-20, while in the control group $85 \%$ of the students got from $0-10,5 \%$ of students got from 11-13, $10 \%$ of students got from 14-16 and 0\% got from 17-20. Based on this information, we can recognize that the experimental group's vocabulary developed better than the control group.

Also, Alemi (2010) directed a study related to this topic where 60 students were randomly chosen from a group of 100 third grade of junior high school students. They were divided into two identical groups; control and experimental. The instruments which were utilized to measure students' level were a proficiency pretest which consisted of questions regarding vocabulary, structure, expressions and pronunciation and an achievement posttest which was similar to the pretest in its form. Based on the findings of the research, games have been shown to have a positive effect on students' performance, for they involve and engage the student in the learning process and draws connections between students and teachers. Games help students develop associations for words which can later affect their other skills

Furthermore, Benoit (2017) directed a research in which six teachers and 60 nonnative students from enrolled in sixth grade, from Northwest Georgia, participated in this study. The participants spoke Spanish,
French, Russian, Chinese, Gujarat, and Creole as their first language. The first instrument that was used in the study was the ACCESS to measure students' English proficiency. The second instrument was the Measure of Academic Vocabulary (MAV) which is a modified vocabulary scale. The study lasted for almost two months. After the analyses of the results, they showed no significant difference in the performance of the control and experimental group. It was recommended to conduct similar studies but with a bigger sample of students to successfully measure the effect of games on students' performance.

The major problem of this study is to determine the effectiveness of using games in the educational process and its impact on learners' lexical development. This research seeks to answer the following question: Are there statistically significant differences in the performance of students in the pretest and posttest?

This study contribute to the development of the educational system in Palestine since the educational methods in this country have not changed over the last century. Hopefully, this study helps teachers to apply untraditional teaching methods, student-centered techniques inside the classroom, that stand in opposition to the traditional, teacher-centered methods which are applied in schools in Palestine. The results of this study is informative regarding whether games are beneficial or not in the educational process.

\section{METHOD}

The researchers present in this section the design of the study, the participants' characteristics, the instruments, and procedure. Finally, they explain data analysis. This is a descriptive study. The data for this study was collected through pretests and posttests and class observation.

The study was conducted at DarAssalam School in Hebron, Palestine. The study included 20 randomly chosen students (Ten males and ten females). The participants were in the third grade (eight students) and in 
the fourth grade (twelve students), and their ages ranged between eight and nine years old $(M=8.5)$. None of the students suffered from neither physical nor mental disabilities, yet, a male student, who is in the fourth grade, was observed to have minor concentration problems, where the participant got distracted easily, was not able to answer consistently; would go off topic in his response, and would not maintain eye contact. Other than that, students, in general, were energetic and eager to attend and participate in class.

In order to achieve the aim of this research, two instruments were used. The first instrument was class observation, in which the researchers observed students' reactions toward games (which games they favored and which ones they did not like), and their performance, as individuals, inside the classroom. The second instrument was pretest and posttest. Since participants were in the third and fourth grade, the researchers designed a pretest for each grade (see Appendix A and B). Furthermore, the test consisted of vocabulary which students had already learned, and it was divided into three questions of 20 overall points. For question one, students had to write the words in the box next to the suitable picture; it was of eight overall points. The second question consisted of six words, three words in Arabic and three words in English, and students had to write the equivalent of each word in the other language; it was of six overall points. Finally, the third question consisted of six pictures and next to each picture four words were written where learners had to choose the correct meaning; it was of six overall points. The form of the posttest was similar to that of the pretest. Yet, unlike the pretest which was two versions, the posttest was one version only, consisting of vocabulary which was discussed during class

In order to measure the effectiveness of games inside the classroom, the researchers approached the administration of DarAssalam School in Hebron, talked to the principle, and got the permission to carry out the research in the school, on Saturdays, once a week and for two months during the first semester of the academic year 2018/2019. In the first meeting, the researchers started the class by introducing themselves and talking about the nature of the upcoming five meeting. After that, they divided the class into two groups (thirds graders and fourth graders), distributed the tests for the third graders (see Appendix A), (fourth graders were given drawing sheets at the same time, to keep them distracted). After third graders finished, tests were distributed to fourth graders (see Appendix B), whereas third graders got the drawing sheets. The groups were given enough time to finish the test and hand back the papers. This whole process lasted, approximately 35 minutes. The posttest (see Appendix C) was given by the end of the first semester of the academic year $2018 / 2019$. Students were given enough time, which was approximately 25 minutes, to answer the test.

\section{RESULTS AND DISCUSSION}

The study aims to figure out the efficiency of using games inside classrooms. To help answering the researchers' question, a pretest and posttest were given to third and fourth grade students. The researchers used PASW statistics, formerly known as SPSS Statistics, to analyze the collected data with the use of paired two samples t-test.

Table 1. Paired samples statistics

\begin{tabular}{cccc}
\hline & Mean & N & Std. Deviation \\
\hline Pre-test & 10.9500 & 20 & 4.13553 \\
Post-test & 14.8500 & 20 & 3.42245 \\
\hline
\end{tabular}

Table 1 shows the mean, standard deviation, standard error mean of the pre-test and post-test, and the number of participants.
The mean of the pretest is of 10.9, the standard deviation is 4.1 and the standard error mean is 0.92 . Whereas the mean of the 
posttest is of 14.8, standard deviation equals 3.4 and the standard error mean is 0.75 . The analysis of pretest and posttest show that, mean is -2.9 , standard deviation is 2.07 , and sig. $(2-$ tailed $)=0.001$.

According to the Null Hypothesis, if the P-value was more than .05 , it means that there is no difference in students' performance. On the other hand, the Alternative Hypothesis states that if the Pvalue was less than .05 , it means that there is a difference between the two groups in the post-test. In conclusion, the Null hypothesis is rejected by the Alternative hypothesis that is games inside the classroom to help students in learning English language.

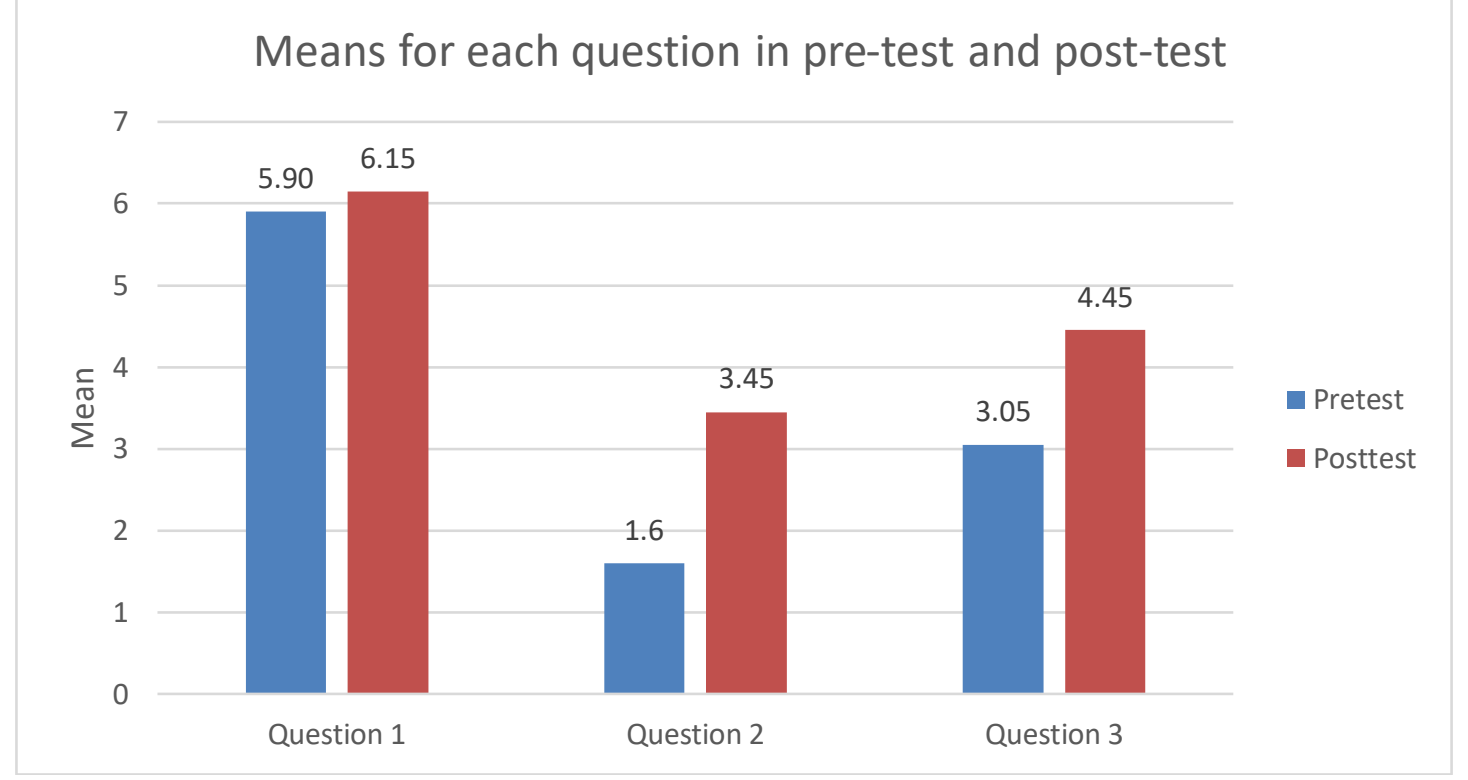

Figure 1. The means for each questions in the pre-test and post-test

In the pre-test, the mean of the first question was 5.90 , the mean of the second question was 1.60 , and the mean of the third question was 3.05. However, in the post-test, the mean of the first question was 6.15 , the mean of the second question was 3.45 , and the mean of the third question was 3.05. 


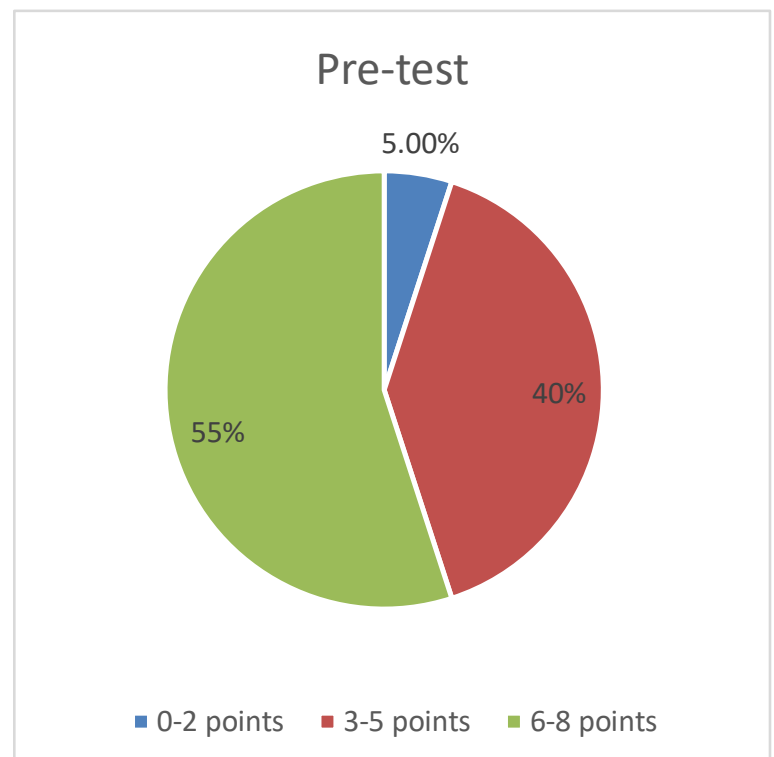

Figures 2. The points got by the students in the first question

In the first question $(\mathrm{M}=6.25$, $\mathrm{SD}=2.02$ ) that was out of eight, $5 \%$ of the students got $0-2$ points, $40 \%$ of the students got 3-5 points; $55 \%$ of the students got $6-8$

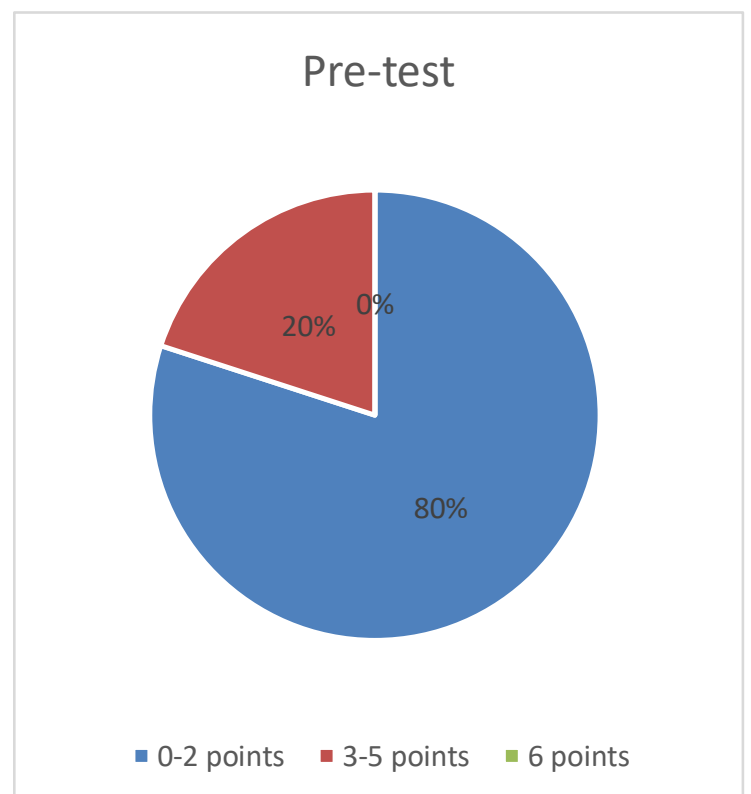

Figure 4. The points got by the students in the second question

Regarding the second question that is out of six, in the pre-test $(\mathrm{M}=1.6, \mathrm{SD}=1.53)$ $80 \%$ of the students got $0-2$ points, $20 \%$ of the students got 3-5 and none of the students

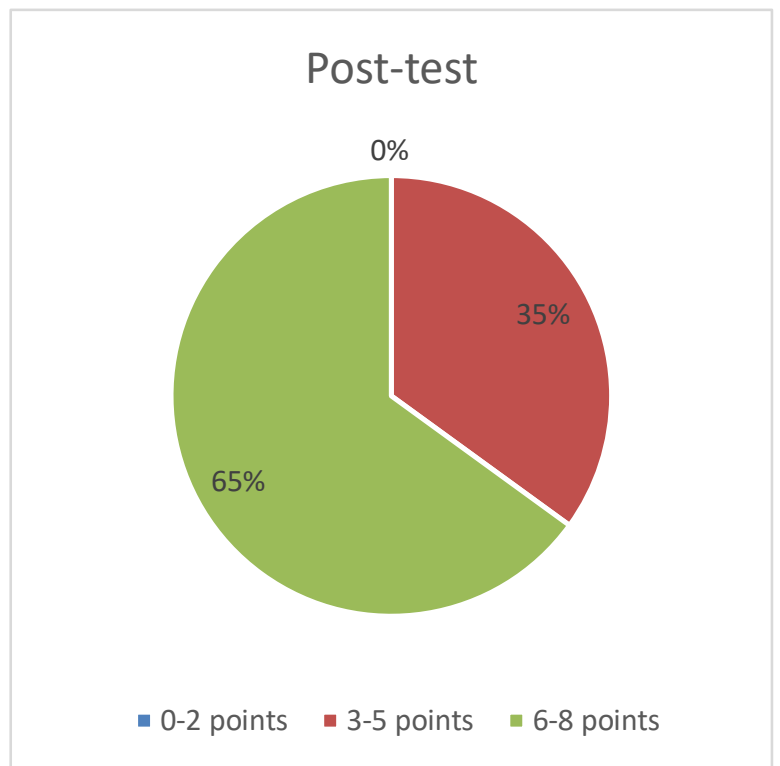

Figure 3. The points got by the students in the first question

points. As for the post-test (M=6.15, $\mathrm{SD}=1.53), 0 \%$ of the students got $0-2$ points, $35 \%$ of the students got $3-5$ points and $65 \%$ of the students got 6-8 points.

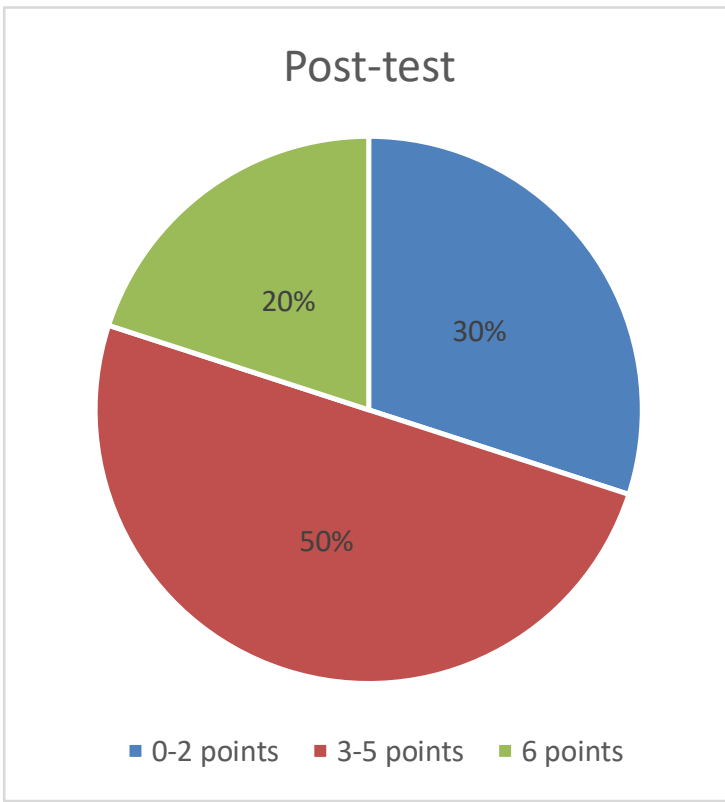

Figure 5. The points got by the students in the second question

got 6 points. In the post-test $(\mathrm{M}=3.45$, $\mathrm{SD}=2.01) 30 \%$ of the students got $0-2$ points, $50 \%$ of the students got $3-5$ points and $20 \%$ of the students got 6 points. 


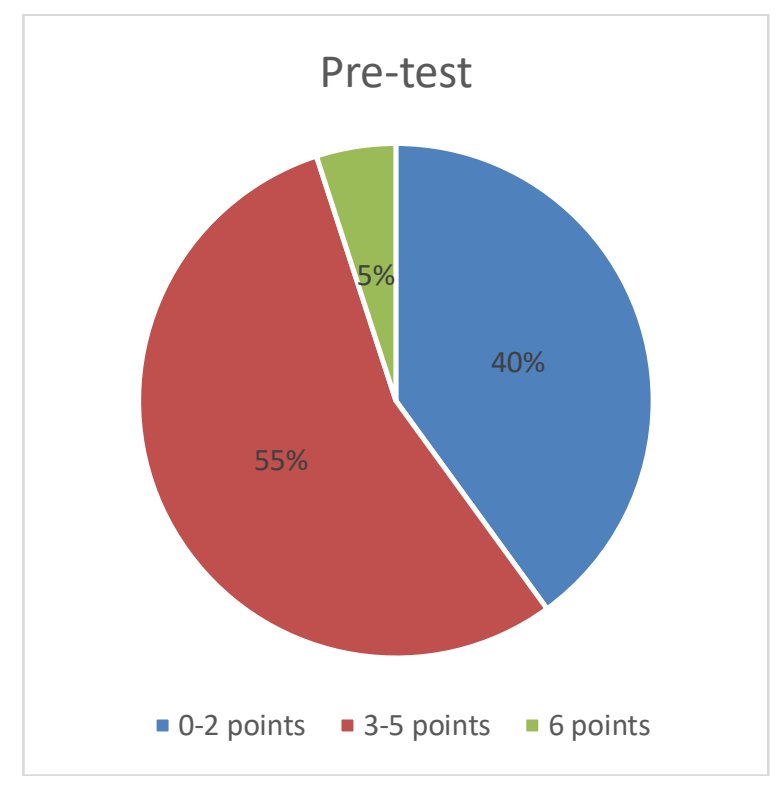

Figure 6. The points got by the students in the third question

Concerning the third question, that is out of six, in the pre-test $(\mathrm{M}=3.05, \mathrm{SD}=1.36)$ $40 \%$ of the students got $0-2$ points, $55 \%$ of the students got 3-5 points and 5\% of the students got 6 points. Where in the post-test $(\mathrm{M}=4.45, \mathrm{SD}=1.32), 10 \%$ of the students got 0-2 points, $60 \%$ of the students got 3-5 points and $30 \%$ of the students got 6 points.

As for observation, the researchers noticed some change in students' behavior. For instance, children who were energetic from the beginning of the experiment remained the same, yet a number of children who were somehow shy and refused to participate at the beginning became more active towards the end. Also, whenever learners were placed into groups and competed against each other, they would answer spontaneously. Furthermore, students liked activities that involved them writing on the board more than others.

After conducting this research for two months, the researchers came to the result that games inside the classroom have a positive effect on students' vocabulary performance. According to the null hypothesis, if the P-value was more than 0.05 , it means that there is no significant difference between the pretest and posttest results. Yet, since in this research the P-value

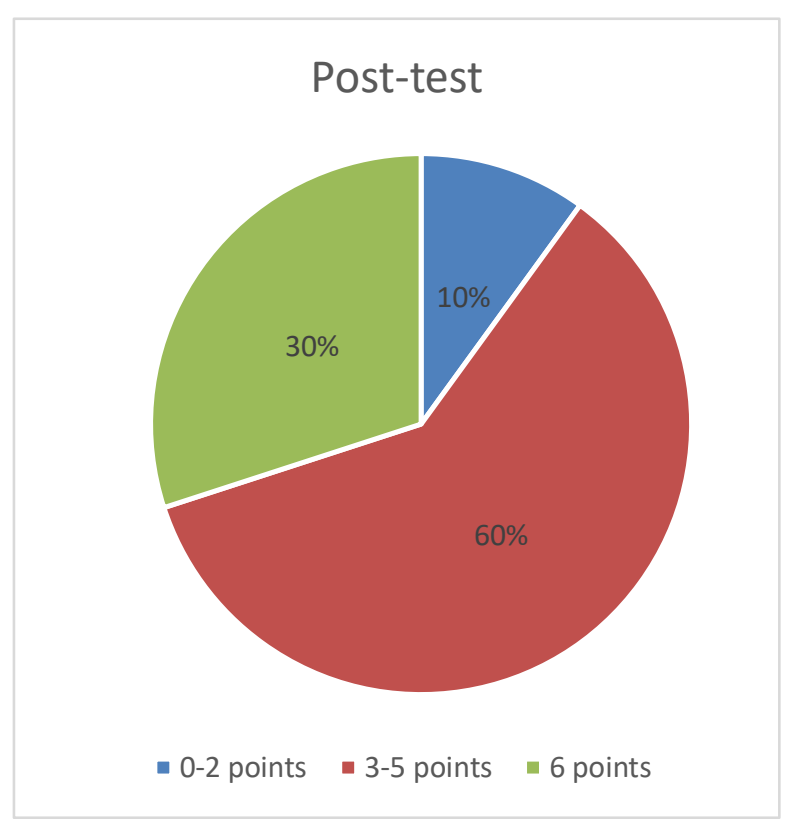

Figure 7. The points got by the students in the third question

equals 0.001 ; this indicates the difference in learners' performance. In other words, games affect learners positively. These results come in line with the findings of Iten and Petko (2013), Gruss (2016) and others.

Regarding students' performance in each question in the pre-test, the researchers found a huge difference between the performance in the first question in comparison with the second and third questions. In the pre-test, in the first question, students had high scores.

This is most likely due to the pictures that were included in the question, which probably facilitated recalling the correct meanings of the words. Although, the third question included pictures, students had lower scores. Most students, if they did not choose the correct answer, they chose one that sounds similar to it. Obviously, they could not differentiate the spelling of the given words. Furthermore, students had the lowest scores in question two that did not contain any pictures. This clarifies that students face difficulty in connecting words to their meanings without the association of other factors. This is probably a result of the traditional education that depends on memorizing instead of linking new information to real life material or events. 
As for question one, in the post-test, learners' scores were similar to the pre-test; with a slight increase. Nevertheless, there was a distinct increase in their performance that was clear in the second and third questions. Even in question two, which did not include pictures, students were able to recognize and recall the correct meaning of words. This is a result of associating unfamiliar vocabulary with pictures, sounds, facial expressions, games, activities, etc. which emphasizes Derakshan (2015) and Bavi (2018) ideas about how games facilitate and help students retain vocabulary.

Likewise, activities that involved students' getting out of their chairs and write on the board were the activities that students favored most. This is due to the fact that students do not like sitting in their chairs, yet they like to move around. Also, whenever students were grouped, they would answer impulsively. This is probably because they were encouraged and felt secure in the sense that other students will help them if they made a mistake. This results in improving students' speaking and listening skills. Teamwork increases the dynamic in the class (Milczynski, 2011), which makes students eager to participate and be active learners.

\section{CONCLUSION}

The educational process is the process of receiving, absorbing and understanding these information. In order for students to keep and benefit from what they learn at schools, they have to receive it in an interesting manner or technique and associate it with their surroundings. Games can provide these requirements.

Whenever games are used in classrooms, learners feel relaxed and calm (Wechselberger, 2013). When a number of students play and participate in a certain activity, other students, who might be shyer, feel comfortable to contribute as well. Moreover, games help developing students' speaking, listening and communicative skills. Also, games enhance team spirit which helps students socialize and interact with others.
In addition, games provide a positive experience for teachers as well as students. They help lecturers to be creative in their teaching methods, and students to be active and creative in their answers. In other words, games help widen thinking in different aspects. Games help students in shaping their intellect, enhancing their skills and absorbing information in an efficient manner.

Nonetheless, teachers have to notice which games students prefer. Also, they have to learn how to present information efficiently through games and adjust activities according to the students' age, abilities, or interests. Games are a sufficient medium through which teachers can deliver information, yet they have to learn the correct way to do it.

It is recommended to do further research on this topic on Palestinian teachers; or students. It is also advised to lengthen the period of the experiment. Moreover, the researchers recommend conducting the research on a bigger sample of participants in order to elicit more information about their performance and attitudes to improve the educational system and methods in Palestine.

\section{REFERENCES}

Adams, M. (2016). Active learning strategies for middle and secondary school teachers. Indiana: Indiana State University.

Alemi, M. (2010). Educational games as a vehicle to teaching vocabulary. The Modern Journal of Applied Linguistics, 2(6), 425-438.

Al-Saqqaf, A., \& Busaidi, S. (2015). English spelling errors made by arab speaking students. English Language Teaching, 8(7), 181-201.

Bavi, F. (2018). The effect of using fun activities on learning vocabulary at the elementary level. Journal of Language Teaching and Research, 9(3), 629-639.

Benoit, J. (2017). The effect of game based learning on vocabulary acquisition for middle school english language learners. Liberty University: Lynchburg.

Celik, S. (2014). Communicative language teaching. Research Gate, 183-199.

Derakhshan, A. \& Khatir, E. (2015). The effect of using games on english vocabulary learning. Journal of Applied Linguistics and Language Research, 2(3), 39-47

Dewey, J. (1938). Experience and education. New York: Simon \& Schuster. 
Indonesian Journal of Learning and Instruction Volume 2, Issue 1, April 2019

Farrah, M. (2011). Online communication and enhancing language skills, motivation, and cultural understanding. The AUC TESOL Journal (AUCTJ), (2). Retrieved from http://www.aucegypt.edu/huss/eli/TESOL/issue s/Pages/Home.aspx

Farrah, M. (2014). The role of demographic and personal variables on the Palestinian Students' perceptions of a blended learning English class. An-Najah Univ. J. Res. (Humanities), 28(4), 993-1026.

Ferreira, L. (2007). How to teach vocabulary effectively: An analysis of the book course eyes and spies. Praia.

Ferreira, L. H. F. (2007). How to teach vocabulary efficiently: An analysis of the course book eyes and spies. Praia: Juri.

Garris, R., Ahlers, R. \& Driskell, J. E. (2002). Games, motivation, and learning: A rashers and practice model. Simulation and Gaming, 33(4), 441-467.

Giannakos, M. (2013). Enjoy and Learn with Educational Games: Examining Factors Effecting Learning Performance. Computers and Education, 68, 429-239.

Gruss, J .(2016). Games as a tool for teaching English vocabulary to young learners. World Scientific New, 53(2), 67-109.

Iten, N., \& Petko, D. (2013). Learning with serious games: Is fun playing the game a predictor of learning success. British Journal of Educational Technology, 47(1).

Jabali, O \& Abuzaid, Y. (2017). Pronunciation errors committed by Palestinian students at An-Najah National University: An analytical approach. Arab World English Journal, 8, 119-131.

Kolb, D. A. (1984). Experiential learning: Experience as the source of learning and development. Englewood Cliffs, NJ: Prentice-Hall.

Lorenzutti, N. (2016). Vocabulary Games: More Than Just Wordplay. English Language Forum, 54(4).

McDonald, S. (2017). Enhanced Critical Thinking Skills Through Problem-Solving Games in Secondary Schools. Interdisciplinary Journal of E-skills and Life Long Learning, 5(13), 7996.

Milczynski, K. (2011). Effectiveness of gaming in the classroom. Michigan: Michigan State University.

Moore, P. (2016). Active learning definitions. Nebraska: UNMC College of Medicine Curriculum Leadership.

Nunan, D. (1989). Designing tasks for the communicative classroom. England: Cambridge University Press.

Nuraihan, M., Daud, \& Farrah, M. (2013). Quality benchmarking for online writing course: A Malaysian case study. World Applied Sciences Journal, 21, 117-124.
p-ISSN 2614-8250, e-ISSN 2614-5677

https://journal.uniku.ac.id/index.php/IJLI
Onyesolo, M., Nwasor, V., Ositanwosu, O.,\& Iwegbuna, O. (2013). Pedagogy: Instructivism to socio-constructivism through virtual reality. International Journal of Advanced Computer Science and Applications, 4(9).

Quick, J. M., Atkinson, R. K., \& Lin, L. (2012). The Gameplay Enjoyment Model. International Journal of Gaming and Computer Mediated Simulation (IJGCMS), 4(4), 64-80.

Quispe, M. (2016). The use of languge games and the level of vocabulary in English in the students of 3rd year of primary school of Americana Adventist School, Juliaca-2014. Peru: University of Piura.

Raba, A. (2014). Using Games to Promote Students' Motivation Towards Learning English. Nablus: An-Najah National University.

Rass, R. (2015). Challenges face Arab students in writing well-developed paragraphs in English. English Language Teaching, 8. doi:10.5539/elt.v8n10p49.

Richards, J. C (2006). Communicative language teaching today. England: Cambridge University Press.

Richards, J. C., \& Rodgers, T. S. (2014). Approaches and methods in language teaching. England: Cambridge Uneversity Press.

Safraz, S., Mansoor, Z., \& Tariq R. (2015). teachers' and students' perceptions of the communicative language teaching methodology in the CALL environment: A case study. Procedia - Social and Behavioral Science, 199, 730-736

Saha, S., \& Singh, S. (2016). Game based language learning in ESL classroom: A theoretical perspective. ELT Vibes: International $E$ Journal for Research in ELT, 2(3), 20-34.

Sardone, N. (2010). Digital games for english classroom. Teaching English with Technology, 10(1), 35-50.

Schifter, C. (2013). Games in learning, design, and motivation. In M. Murphy, S. Redding, \& J. Twyman (Eds.), Handbook on innovations in learning (pp. 149-164). Philadelphia, PA: Center on Innovations in Learning, Temple University; Charlotte, NC: Information Age Publishing. Retrieved from http://www.centeril.org/

Shehadeh, I., \& Farrah, M. (2016). The effectiveness of using children's songs in developing elementary graders' English vocabulary and pronunciation in Jerusalem, Palestine. Journal of Creative Practices in Language Learning and Teaching (CPLT).

Sweetser, P., \& Wyeth, P. (2018). Gameflow a model for evaluating player enjoyment. Australia: The University of Queensland.

Wechselberger, U. (2013). Learning and enjoyment in serious gaming - contradiction or complement? In Proceedings of DiGRA 2013: DeFragging Game Studies. Atlanta: GA. 


\section{Yasmin Shabaneh \& Mohammed Farrah}

The effect of games on vocabulary retention

Wilkins, D. (1972). Linguistics in language teaching. London: Arnold.

Willis, J. (1996). A framework for task-based learning. London: Longman.

Yavuz, A. (2010). Enhancing creativity in the communicative language classroom through poetry as a literary genre. Dil Dergisi, 149, 4663

Zirawaga, V., Olusanya, A. \& Maduku, T. (2017). Gaming in education: Using games as a support tool to teach history. Journal of Education and Practice, 8(15), 55-64. 